\title{
Effects of Farallon slab subduction on the halogen budget of the North American lithosphere
}

\author{
John C LASSiter ${ }^{1}$, JAIMe D BARNeS ${ }^{1}$, Alex Holmes ${ }^{1}$, \\ GEORGE H SEgEe-Wright ${ }^{1}$, Grace M BEAUdoin ${ }^{1}$, \\ ELIS HOFFMANN $^{2}$, TIMM JOHN ${ }^{2}$ \\ ${ }^{1}$ Dept. Geol. Sci., Jackson School of Geoscience, U. Texas, \\ Austin, TX; lassiter1@jsg.utexas.edu \\ ${ }^{2}$ Inst. Geol. Wiss., F. U. Berlin
}

Flat subduction of the Farallon slab modified the North American SCLM through introduction of slab-derived components. Halogen concentrations in mantle xenoliths from the Navajo Volcanic Field (NVF), Colorado Plateau, Cerro Chato (CC; eastern Colorado Plateau margin) and Elephant Butte (EB; central Rio Grande Rift) constrain the effects of Farallon-related metasomatism on halogen abundances.

Most xenoliths from $\mathrm{CC}$ and $\mathrm{EB}$ have low $\mathrm{Cl}$ and $\mathrm{F}$ abundances (ave. 4.8 and $24 \mathrm{ppm}$ respectively). Average $\mathrm{Cl} / \mathrm{Nb}(\sim 11)$ and $\mathrm{F} / \mathrm{Nd}(\sim 31)$ ratios are similar to MORB/OIB and to olivine-hosted melt inclusions from these locations (Rowe et al., 2015). No correlations are observed in halogen abundances or ratios with indices of metasomatism or melt depletion (e.g., LREE-enrichment or $\mathrm{Cr} \#$ ). Thus, evidence for significant $\mathrm{Cl}$ or $\mathrm{F}$ input from Farallon-slab-derived fluids is lacking. In contrast, xenoliths from the NVF have much higher $\mathrm{Cl}$ abundances (ave. $205 \mathrm{ppm}$ ) but similar $\mathrm{F}$ abundances (ave. $14 \mathrm{ppm}$ ). Despite their $\mathrm{Cl}$ enrichment, the NVF samples do not show any correlation between $\mathrm{Cl}$ and other indices of metasomatism.

The heavy halogens $(\mathrm{Br}$ and $\mathrm{I})$ are strongly enriched in both the NVF and the CC/EB xenoliths, with I concentrations ranging up to nearly $800 \mathrm{ppb}$ in the $\mathrm{CC} / \mathrm{EB}$ xenoliths. $\mathrm{I} / \mathrm{Cl}$ and $\mathrm{I} / \mathrm{Br}$ ratios are elevated relative to $\mathrm{MORB} / \mathrm{OIB}$. These enrichments contrast with low $\mathrm{Br}$ and $\mathrm{I}$ abundances in southern Rio Grande Rift xenoliths (San Carlos and Kilbourne Hole; Kobayashi et al, 2019), but are similar to western Antarctic xenoliths (Broadley et al, 2016), and may reflect heavy halogen addition from slab-derived fluids.

The decoupling of halogen abundances from each other and from other proxies for addition of slab melt or fluid (e.g., $\mathrm{Ba} / \mathrm{Nb}, \mathrm{Sr} / \mathrm{Nd}$ ) suggests that halogens may derive from multiple sources, including subducted sediments and serpentinized peridotite. Detailed examination of regional variations may therefore provide constraints on slab-mantle volatile fluxes along an evolving P-T-t pathway.

Rowe et al., $\mathrm{G}^{3}$, 2015; Kobayashi, et al., $\mathrm{G}^{3}, 2016$; Broadley et al., GCA, 2016. 